\title{
Sustainable Development and Gas Flaring Activities: a Case Study of Ebedei Area of Ukwuani LGA, Delta State, Nigeria
}

\author{
Vincent Nduka Ojeh \\ Department of Geography, Regional Planning Delta State University, PMB 1, Abraka, Nigeria \\ vinceojeh@yahoo.com
}

\begin{abstract}
The impact of gas flaring on the sustainable development was examined. The presence crude oil and natural gas is expected to serve as socio-economic driver of accelerated sustainable development of an area but the situation of oil producing areas of Nigeria is a far cry from the expected. Data was collected from eight (8) experimental sites around the gas flaring station including Obiaruku (control site), which has no gas-flaring station. Temperature and concentrations of air quality indices were determined. The temperature and air quality measurements in Ebedei were made, at least, 50 meters away from the bund wall of the flare. The data were analysed using the Multiple Regression and bivariate correlation. Results revealed that there is a significant relationship between ambient temperature and the gases $\left(\mathrm{CO}, \mathrm{NO}_{2}, \mathrm{SO}_{4}\right.$ and $\left.\mathrm{CH}_{4}\right)$ flared in Ebedei at $\mathrm{F}$ value of 20.069 which is greater than the critical value of 9.12. An increase in flared gases results to a corresponding increase in temperature. Strong negative relationship exists between distance from the bund wall of the flare and temperature at $r=0.855$. Recommendations: (FEPA) should constantly monitor and evaluate the level of damages done by gas flaring to ensure compliance and sustainability of the environment.
\end{abstract}

Keywords Gas Flaring Activities, Temperature Variations, Sustainable Development, Pollution, Ebedei, Ukwuani LGA

\section{Introduction}

The environment provides all life support systems with air, water and land as well as the materials for fulfilling all developmental aspirations of man. The Nigerian environment today presents a grim litany of woes[1]. The problem of sustainable development has attracted the attention of not only academic scholars in developmental researches, but also of activists, politicians, development workers and international organization for many years with an increased tempo in the last ten years. This is because it is no longer fashionable to treat the environment with levity as was done in the past. But experiences in Nigeria shows that of non-commitment to environmental justice and sustainable development especially in the Niger Delta region where the presence of oil and gas seem to be more of pain than blessing to the masses. Little wonder the area has been christened 'where the Vulture feast'[2]. According to Ress[3], "Sustainable Development is positive socioeconomic change that does not undermine the ecological and social systems upon which communities and social systems are dependent"

There is a general consensus that development will lead to.

* Corresponding author:

vinceojeh@yahoo.com (Vincent N. Ojeh)

Published online at http://journal.sapub.org/re

Copyright $(2012$ Scientific \& Academic Publishing. All Rights Reserved good change manifested in increased capacity of people to have control over material assets, intellectual resources and ideology; and obtain physical necessities of life(food, clothing \& shelter), employment, equality, participation in government, political and economic independence, adequate education, gender equality, sustainable development and peace[4]. The experience of people in the study area is a far cry from achieving sustainability in development as a result of gas flaring and if not checkmated is capable of undermining socioeconomic development and environmental justice.

It suffices here to say that the goal seven of the Millennium Development Goals(MDGs) is to ensure environmental sustainability while the targets are: Target 7a: Integrate the principles of sustainable development into country policies and programmes; reverse loss of environmental resources; Target 7b: Reduce biodiversity loss, achieving, by 2010, a significant reduction in the rate of loss; Target 7c: Reduce by half the proportion of people without sustainable access to safe drinking water and basic sanitation and Target, etc. These targets are far from being achieved owing to the insincerity of the oil companies and government which is a major stakeholder in the actualization of the MDGs. Consequently, the tales of youth restiveness and communal clashes is still prevalent in the area.

The threat to human life posed by pollution due to gas 
flaring cannot be undermined. The impact of gas flaring is of both local and global concern. The mixture of toxic substances emitted from flares containing benzene particles exposes communities to severe health risks. These huge deposits of gas are associated with crude oil in the oil deposits of Nigeria. The consequence of this flaring is the emission of carbon dioxide, methane gas and other associated gases. The flared gas releases pollutants like carbon (C), nitrogen dioxide $\left(\mathrm{NO}_{2}\right)$ sulphur dioxide $\left(\mathrm{SO}_{2}\right)$ and lead $(\mathrm{Pb})$ into the atmosphere[6]. This associated gas, a by-product of the country's lifeline petroleum exploration activities is separated from the oil at flow station and more than $95 \%$ of it is flared on the whole. The preservation of the environment is an essential factor for sustainable development and poverty reduction[7].

Carbon dioxide and methane are the main greenhouse gas implicated from gas flaring activities and consequently, this phenomenon has been confirmed to raise the average global temperature by about $0.5^{\circ} \mathrm{C}$ within the last century[11,12] . The flaring station in the Ebedei is been blamed for smoke and flames that pollute the air and soil quality in the ecologically fragile area and contribute to the global greenhouse gases. Heat and noxious gases may contribute to environmental health problem in the study area. Also, there has been timely warming in Ebedei resulting from heat radiation which is a function of the flare temperature, gas flow rate and geometrical design of flare stack. Succinctly, heat from gas flares affects the microbial populations[23], which participate in organic matter decomposition and nitrogen formation process resulting in a decline in organic matter and total nitrogen, as well as microbial populations, humid (top soil) formation, nutrient availability and soil fertility.

In Ebedei, gas flaring is the major source of thermal pollution which causes a distinct micro-climate around the vicinity of operation. However, the environmental policies and regulations can be conveniently characterized as minimal and poor, as the government puts profits ahead of the environment and the welfare of its citizens. Consequently, the need to examine gas flare and temperature variations is of necessity to this study. Focus will be placed on Ebedei because it is an area where oil drilling and gas flare activities is prominent. This research is geared to provide information available on the effects of gas flaring.

\section{Study Area}

Ebedei is situated in the Niger Delta region which is rich in oil and gas. It lies between latitude $5^{\circ} 51^{\prime} \mathrm{N}$ and $6^{\circ} 10^{\prime} \mathrm{N}$ and longitude $5^{\circ} 10^{\prime} \mathrm{E}$ and $5^{\circ} 48^{\prime} \mathrm{E}$ of Ukwuani Local Government Area (Figure 2). Ebedei is characterized by hydromorphic soils, which is a mixture of coarse alluvial and colluvial deposits. The area is drained by the River Ethiope and one of its tributaries, the Orogodo River which only flows into the River Ethiope during the rainy season. The climate is of the tropical equatorial climate with mean annual temperature of $27.32^{\circ} \mathrm{C}$, average relative humidity of about $60 \%-80 \%$ and annual rainfall amount of $4205 \mathrm{~mm}$. Generally, two major wind systems influence the climate of Ukwuani. These are, the northeast trade wind blowing cold dry air from the Sahara and the southwest trade wind blowing cold moist air from the Atlantic. The South-West wind prevails almost throughout the year, from March-October, while the North-East trade wind is responsible for the cold dry period (Harmattan) which influences the area for about four months (November-February).

This brings about two types of seasons within a year; the rainy and dry seasons, respectively. The vegetation is that of the tropical rainforest belt characterized by dense vegetation cover consisting of evergreen forest of tall trees with undergrowth of climbing plants that are closed together along the streams and creek channels and this normally typifies primary vegetation while the presence of grassland with sparse trees and shrubs typified the secondary vegetation pattern within the vegetation belt.

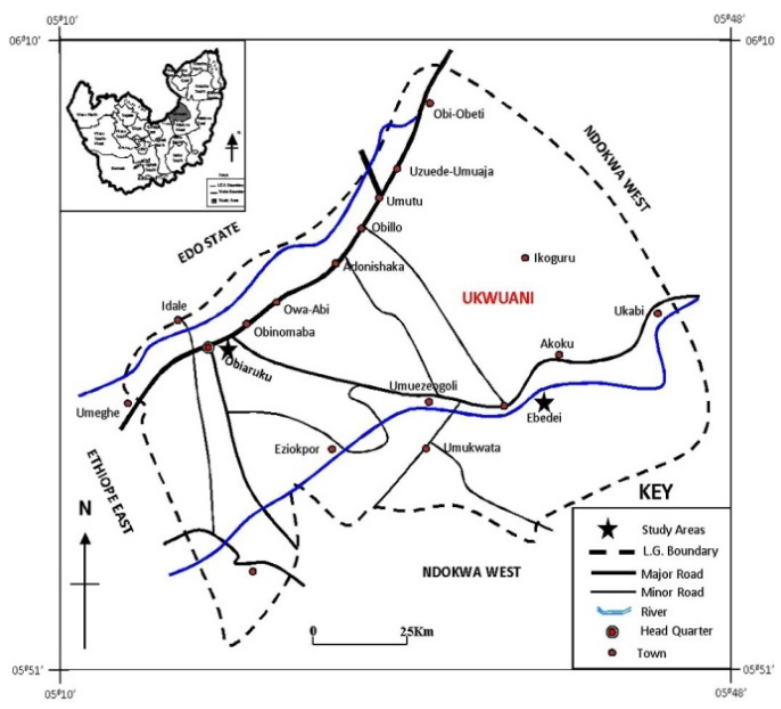

Figure 2. Map showing study area

\section{Conceptual Issues}

The nature of the relationship between gas flaring and ambient temperature may be seen to be a function of facets of extreme climate conditions which confine to Heat Island approach. The links between urbanization and global climate change are complex[13]. In the context of enhanced global warming, towns affect greenhouse gas sources and sink both directly and indirectly. For instance, oil producing areas are the major sources of anthropogenic carbon dioxide emissions from the burning of fossil fuels for heating and cooling; from industrial processes. One of the most well-known anthropogenic climate modifications is the phenomenon of heat Island (HI). The HI describes the increased temperature of air and heat island profile temperatures raising from the rural fringe and peaking in the centre. The concept of heat island has been applied to urban climate research in different parts of the world[14-16].

Emmanuel[17] applied the concept of heat island to his 
study of urban vegetation change as an indicator of demographic trends in cities of Detroit. Furthermore,[15] outline different types of heat island as follows: Canopy layer heat island(CLHI); Boundary layer heat island(BLHI); Surface heat island(SHI). The first two refer to a warming of the atmosphere; the last refers to the relative warmth of surface. The urban canopy layer (UCL) is the layer of air closet to the surface, extending upward to approximately the mean building height. Above the canopy layer lies the boundary layer, which may be 1 kilometer $(\mathrm{km})$ or more in thickness by day, shrinking to hundreds of meters or less at night. It is the boundary layer heat island (BLHI) that forms a dome of warmer air that extends downwind of the city- wind often changes the dome to a plume shape.

Heat island types vary in their spatial form (shape), temporal, (related to time) characteristics, and some of the underlying physical process that contribute to their development. Scientists measured air temperature to CLHI or BLHI directly using thermometers, whereas remote sensors mounted on satellites or aircraft measure the SHI. The heat island effect is reinforced by increased demand for cooling, consequently raising the level of greenhouse gas emissions from power plants. During daytime, suburban-rural differences in net radiation were generally small compared with greater sensible heat, decreased latent heat, and more heat storage at the suburban site than the rural location. This concept of heat island is relevant to this study because it is used to assess the temperature variation emanating from distances of flare point.

\section{Materials and Method}

The study adopted the experimental design which involved measurements of ambient air temperature and air quality index spanning a period of three months (February, March and April) and the mean was used.

Collection of Samples: In doing so, eight (8) experimental sites were systematically selected around the flare site in Ebedei using an equidistance of $50 \mathrm{~m}, 150 \mathrm{~m}, 250 \mathrm{~m}$, $350 \mathrm{~m}, 450 \mathrm{~m}, 550 \mathrm{~m}, 650 \mathrm{~m}$ and a control site at Obiaruku having a distance of $1700 \mathrm{~m}(17 \mathrm{~km})$ from the flare bund wall. The choice of the distance of the control site represents the statistically insignificant effect which is beyond $15 \mathrm{~km}$ and $20 \mathrm{~km}$ radius of the flare site as opined by Onuorah[18] and Odjugo[19]. Again, both the experimental sites and control site were within the same climatic and soil zone, but the control site is not a gas flared area, so any observed differences as distance decay from flare sites could be attributed to the effect of the gas flaring.

The temperature measurement was done by the use of a thermometer. The temperature reading was taken at a height of $3 \mathrm{~m}$ between $9.00 \mathrm{~h}$ and $11.00 \mathrm{~h}$ GMT to minimize the effect of vertical temperature gradient and for uniformity of weather conditions respectively. The air quality index measurements was carried out using a gas meter during early hours of morning $(7 \mathrm{am})$ and evenings $(7 \mathrm{pm})$. This time dura- tion was selected as a result of the volatile nature of the gases. The data on ambient temperatures and air quality index was averaged from records of the designated distances from flare wall bunds. Multiple Regression and bivariate correlation analyses were used to ascertain the relative impact of flare gases and ambient temperature; and distance from the bund wall of the flare and temperature. The main components of flared gases include carbon dioxide $\left(\mathrm{CO}_{2}\right)$, methane $\left(\mathrm{CH}_{4}\right)$, nitrous oxide $\left(\mathrm{NO}_{2}\right)$, water vapour and sulphur dioxide $\left(\mathrm{SO}_{2}\right)$. The low combustion efficiency of Nigeria flare stack $(60-80 \%)$ results in a large portion of the gas emitted being methane and since methane has a higher global warming potential[8]. The role of methane in global atmospheric changes has received increasing attention recently[9]. Although the actual emission is estimated with a great deal of uncertainty, yet methane has a global warming potential up to 63 times to that of carbon dioxide(depending on the time horizon) and accounts for about $15 \%$ of the global warming due to anthropogenic emissions[10] as shown in Table 1.

Table 1. Greenhouse Gases Emission

\begin{tabular}{|c|c|}
\hline GHG & Percentage \\
\hline $\mathrm{CO}_{2}$ & 55 \\
$\mathrm{CFC}$ & 24 \\
$\mathrm{CH}_{4}$ & 15 \\
$\mathrm{NO}_{2}$ & 6 \\
\hline
\end{tabular}

Source: Brown and Maunder[10]

Ebedei is part of the Niger Delta which is the hub of oil industry in Nigeria. Crude oil in Niger Delta region contains great proportion of associated gas. Huge volumes of associated gas are usually released during production of crude oil. The region has about 40 billion bbl proven oil reserves and 187 trillion cubic feet of natural gas[5]. Daily oil production is about 2.4 million bbl and 3.5 billion cubic feet/day natural gas production of which over $90 \%$ of gas produced daily is flared (Figure 1).

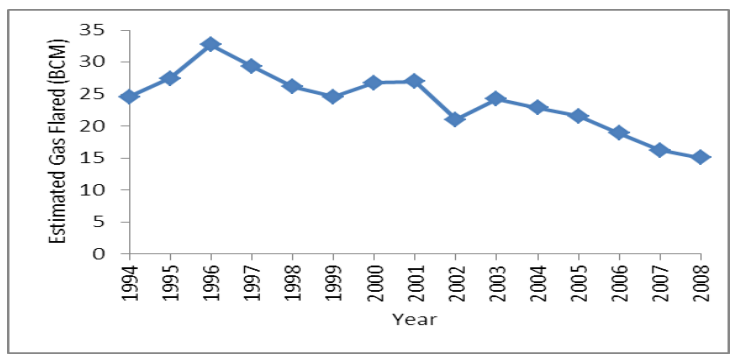

Figure 1. Trend of gas flared in billion cubic metre (BCM) in Nigeria from 1994-2008

\section{Results and Discussion}

Table 2. Temperature variation along distance from flare bund wall

\begin{tabular}{|l|c|c|c|c|c|c|c|c|}
\hline $\begin{array}{l}\text { Distances } \\
(\mathbf{m})\end{array}$ & 50 & 150 & 250 & 350 & 450 & 550 & 650 & 1700 \\
\hline $\begin{array}{l}\text { Temperature } \\
\left({ }^{\circ} \mathrm{C}\right)\end{array}$ & 29 & 28.9 & 28.5 & 28.5 & 28.2 & 27.8 & 27.6 & 27.2 \\
\hline
\end{tabular}

***Control Site located at Obiaruku 
Table 2 shows observed ambient temperature versus distance away from the flare point. The temperature decreases with increasing distance away from the flare point. The mean temperature of the study area is $28.2^{\circ} \mathrm{C}$. Therefore, the surface temperature along the distances normalized at $28.2^{\circ} \mathrm{C}$ within a distance of $450 \mathrm{~m}$ away from the flare point. Thermal air pollution occurs if the recorded air temperatures of the place deviate from its normal ambient temperature[20]. This increase in temperature has an undesirable effect on $\operatorname{man}[21]$.

Table 3 shows the volume of gases emitted from varying flare distances. Values obtained for all the parameters $(\mathrm{CO}$, $\mathrm{NO}_{2}, \mathrm{SO}_{2}$ and $\mathrm{CH}_{4}$ ) from Ebedei were above the FEPA standard/permissible limit for normal environment, and were markedly higher when compared to values for communities in Obiaruku. However, Sulphide (SO2) gas has the highest concentration as a result of their volatile nature (see Figure $3)$.

Table 3. Gas flare distances and flared gases

\begin{tabular}{|c|c|c|c|c|}
\hline \multirow{2}{*}{ Distance(m) } & \multicolumn{4}{|c|}{ Gases flared $\left(\boldsymbol{\mu g} / \mathbf{m}^{\mathbf{3}}\right)$} \\
\cline { 2 - 5 } & $\mathbf{C O}$ & $\mathbf{N O}_{\mathbf{2}}$ & $\mathbf{S O}_{\mathbf{2}}$ & $\mathbf{C H}_{\mathbf{4}}$ \\
\hline 50 & 11.9 & 28.75 & 32.06 & 14.43 \\
\hline 150 & 10.38 & 28.45 & 32.03 & 12.43 \\
\hline 250 & 10.35 & 31.78 & 22.75 & 5.82 \\
\hline 350 & 8.9 & 21.67 & 34.12 & 4.86 \\
\hline 450 & 6.77 & 22.67 & 28.96 & 4.86 \\
\hline 550 & 6.48 & 34.22 & 51.54 & 4.84 \\
\hline 650 & 4.08 & 34.62 & 49.57 & 2.82 \\
\hline 1700 & 2.67 & 15.29 & 19.73 & 2.19 \\
\hline$* * \mathrm{FEPA}$ & 10 & 20 & 20 & 10 \\
\hline
\end{tabular}

** Federal Environmental Protection Agency (FEPA) air quality standards

The mean values of all the air quality indices decreased as the distance from the flaring site increased indicating that gas diffusion increased with increasing distance[22]. This observation is attributed to the high pollution level due to gas flaring in Ebedei, although the mean values for both $\mathrm{CO}$ and $\mathrm{CH}_{4}$ are below FEPA standards. Note that at the further distance, lesser concentration of the pollutants. This could be attributed to the fact the pollutants are engaged in other reaction due to dispersion of pollutants and other components.

It could be seen from Table 3 that the most dangerous zone is within the $50-350 \mathrm{~m}$ radius from the flare station. However, the effects of gas flared are felt within the radius range of $450 \mathrm{~m}$ away from the flaring source depending on the volume of gas flared, wind speed, surrounding temperature, velocity of discharged and height of stack. It could be observed from the results that the concentration of pollutant in the ground level increases as the volume of gas flared increase and vice versa. This growth in concentrations of gases is caused by industrial processes[9].

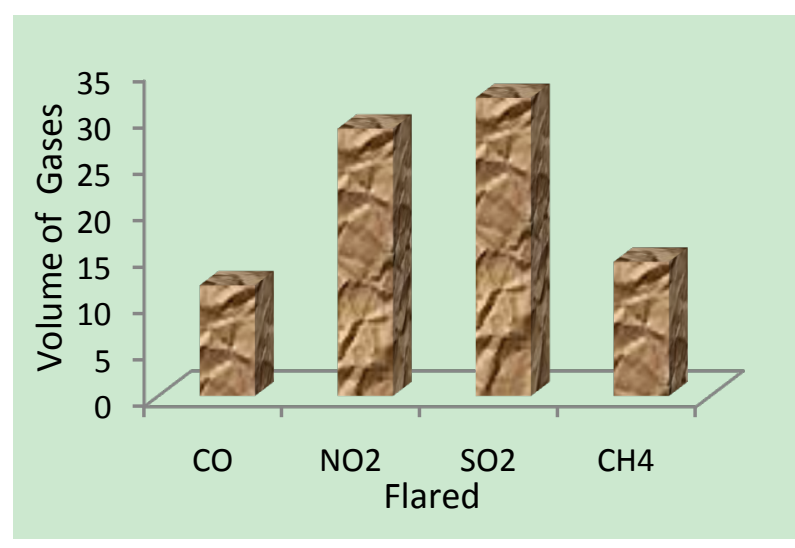

Figure 3. Volume of gas flared

Figure 3, shows that the gases flared are in decreasing order of $\mathrm{SO}_{2}, \mathrm{NO}_{2}, \mathrm{CO}$ and $\mathrm{CH}_{4}$ respectively. This implies that the health of the people in the study area is affected negatively especially those living very close $(50-250 \mathrm{~m}$ distance) to the flare site since the gases are occurring at levels higher that allowable limits of FEPA. If $\mathrm{SO}_{2}$ for example is properly harnessed, it is a food preservative, fumigant, bleaching agent in the manufacture of sulfuric acid while $\mathrm{NO}_{2}$ is a poisonous brown gas not safe for human health.

Table 4 shows that $r^{2}$ value is 0.964 which implies that $96 \%$ of temperature increment is attributed to methane $\left(\mathrm{CH}_{4}\right)$, sulphide $\left(\mathrm{SO}_{4}\right)$, nitrogen oxide $\left(\mathrm{NO}_{2}\right)$ and carbon dioxide (CO) in Ebedei. At $\mathrm{p}<0.05$ significance level, the calculated F value is 20.069 while the critical table value is 9.12 . Thus, there is a significant relationship between temperature and the gases.

Furthermore, from the standardized beta coefficient table, the beta values value shows positive for $\mathrm{NO}_{2}, \mathrm{SO}_{4}$ and $\mathrm{CH}_{4}$ which implies an increase in flare gases results to a corresponding increase in temperature. However, from the significant level the most significant gas that affects temperature the most is carbon dioxide (CO).

Table 6 shows that the temperature observed is strongly correlated with the distance from the bund wall of the flare at $\mathrm{R}=0.885$. Thus $88.5 \%$ of temperature increase is associated to an increase of distance from flare bund wall.

Table 4. Regression statistic summary

\begin{tabular}{|c|c|c|c|c|c|c|c|c|}
\hline \multirow{2}{*}{ Model } & \multirow{2}{*}{$\mathrm{R}$} & \multirow{2}{*}{ R Square } & \multirow{2}{*}{$\begin{array}{l}\text { Adjusted R } \\
\text { Square }\end{array}$} & \multicolumn{5}{|c|}{ Change Statistics } \\
\hline & & & & R Square Change & F Change & df1 & df 2 & $\begin{array}{l}\text { Sig. F } \\
\text { Change }\end{array}$ \\
\hline 1 & $.982^{\mathrm{a}}$ & .964 & .916 & .964 & 20.069 & 4 & 3 & .017 \\
\hline \multicolumn{9}{|c|}{ a. Predictors:(Constant), $\mathrm{CH}_{4}, \mathrm{SO}_{4}, \mathrm{NO}_{2}, \mathrm{CO}$} \\
\hline
\end{tabular}


Table 5. standardized beta Coefficient

\begin{tabular}{|c|c|c|c|c|c|c|}
\hline \multicolumn{2}{|c|}{ Model } & \multicolumn{2}{|c|}{ Unstandardized Coefficients } & \multirow{2}{*}{$\begin{array}{c}\begin{array}{c}\text { Standardized } \\
\text { Coefficients }\end{array} \\
\text { Beta } \\
\end{array}$} & \multirow{2}{*}{$\mathrm{T}$} & \multirow{2}{*}{ Sig. } \\
\hline \multirow{6}{*}{1} & & B & Std. Error & & & \\
\hline & (Constant) & 26.879 & .317 & & 84.807 & .000 \\
\hline & $\mathrm{CO}$ & .181 & .044 & .926 & 4.152 & .025 \\
\hline & $\mathrm{NO} 2$ & -.015 & .017 & -.160 & -.864 & .451 \\
\hline & $\mathrm{SO} 4$ & .007 & .010 & .118 & .655 & .559 \\
\hline & CH4 & .019 & .028 & .136 & .685 & .542 \\
\hline
\end{tabular}

Table 6. Correlation model summary

\begin{tabular}{|c|c|c|c|}
\hline & & Temperature & $\begin{array}{c}\text { Distance from bund wall of } \\
\text { flare }\end{array}$ \\
\hline \multirow{3}{*}{ Temperature } & Pearson Correlation & 1 & $-.885^{* *}$ \\
\cline { 2 - 4 } & Sig.(2-tailed) & & .004 \\
\cline { 2 - 4 } & $\mathrm{N}$ & 8 & 8 \\
\hline \multirow{3}{*}{$\begin{array}{c}\text { Distance from bund wall of } \\
\text { flare }\end{array}$} & Pearson Correlation & $-.885^{* *}$ & 1 \\
\cline { 2 - 4 } & Sig.(2-tailed) & .004 & 8 \\
\cline { 2 - 4 } & $\mathrm{N}$ & 8 & \\
\hline
\end{tabular}

\section{Conclusions}

This study has revealed an increase in temperature alongside with an increase in gas flaring and flare distances in Ebedei area. It is safe to conclude that gas flaring not only produces excessive heat which alters the temperature of the environment, but also causes gaseous pollutants to be present in the environment which may have adverse effects on the inhabitants and thus undermine sustainable development and the achievement of the Millennium Development Goals especially goal seven. The temperature of the environment returns to normal at about $450 \mathrm{~m}$ away from the flare stack. Residential buildings should therefore be located within this range of distance.

\section{Recommendations}

In view of the gas flaring situation at the Ebedei gas plant with respect to the negative socio-economic impacts on the environment, the following are recommended:

a. Oil companies should be compelled to stop gas flaring so as to reduce the detrimental effect of these greenhouse gases on the health and well-being of the inhabitants of areas harbouring the gas flare stations.

b. Gas should not be flared but harnessed with the aid of a gas turbine for electricity generation

c. With reference to Ebedei gas plant, residential areas should be situated at a minimum of $450 \mathrm{~m}$ away from the flare point.

\section{REFERENCES}

[1] Lawanson, T.O. "Challenges of Sustainability and Urban Development in Nigeria: Reviewing the Millenium Development Goals" Africa Insight, pp 1-19, 2006.

[2] Oculi, O., Ike, O. and Oronto, D. "Where Vultures Feast: Shell, Human Rights, and Oil in the Niger Delta (review)" African Studies Review, Volume 50, Number 2, September 2007, pp. 259-260, 2007.

[3] Ress, W. "Sustainable Development: Myths and Realities" in Environment and Economic Partners for the Future. Conference Proceeding, Winnipeg, Government of Manitoba. p3, 1989.

[4] Igbuzor, O. Review of Nigeria Millennium Development Goals - 2005 Report. A Review Presented at the Mdg/Gcap Nigeria Planning Meeting Held In Abuja, Nigeria on 9th March, 2006.

[5] Iyasele, C. Gas Flaring Reduction in the Niger Delta: A Case study of SPDC, retrieved from- http://www.slideshar e.net/iyaselex/gas-flaring-reduction-in-the-niger-delta. 2011

[6] Okoh, N.V. "Environmental impacts of oil exploration". Atmospheric Rev., 12: 68-80, 2000.

[7] Fatoumata, B.A. Ensuring Environmental sustainability in West Africa(MDG 7), United Nations Economic Commission for Africa Sub Regional Office For West Africa, Tracking progress in the implementation of regional and international agendas, including NEPAD and other special initiatives in the sub-region pp 1-32, 2010.

[8] Sawaragi, Y. \& Akashi, H. Environmental system planning design and control, Pergamon Press, New - York, p. 31-32, 1978 . 
[9] Yusuf, R.O. \& Oyewunmi, M.O. Qualitative Assessment of Methane Generation Potential from Municipal Solid Wastes: A case study. Environmental Research Journal, 2(4): 138-144, 2008.

[10] Brown, K.A \& Maunder, D.H. Exploitation of landfills gas: a UK perspective. Waste Science Technology, 30(12): 43 - 151, 1994.

[11] Thomas, J.H. \& Allen, P.J. CNN weather report, 1999, p. 3, 1999.

[12] Penner, J.E. Aviation and global atmosphere, Inter governmental parley on climate change, Cambridge University Press, Cambridge, UK, pp 2-4, 1999.

[13] Sanchez, P.A. Properties and Mismanagement of Soil in the Tropics, John Wiley and Sons, New York, p2-7, 1976.

[14] Buechly, R.W., Bruggen, V. \& Trippi, L.E. "Heat Island Death Island" Environmental Research, 5:85-92,1972.

[15] Oke, T.R. Boundary Layer Climates, London Meth and Co. Ltd, Great Britain, p6, 1981.

[16] Adebayo, Y.R. "Heat Island" in a humid tropical city and its relationship with potential evaporation. Journal of theoretical and applied climatology, 43(3):137-147, 1991.
[17] Emmanuel, R. "Urban vegetation change as an indicator of demographic trends in cities: the case of Detroit" Environment and planning. 24B:415-426, 1997.

[18] Onuorah, A.O. "The oil industry and environmental degradation" Journal of Atmospheric Science, 10: 42-63, 2000

[19] Odjugo, P.A.O. "Some Effects of Gas Flaring on the Microclimate of Yam and Cassava Production in Erhorike and Environs. Delta State, Nigeria”. Nigerian Geographical Journal, 5: 43-54, 2007.

[20] Oseji, J.O. "Thermal Gradient due to Gas Flared at Kokori/Erho-ike Flow Station, Delta State, Nigeria" The Pacific Journal of Science and Technology, 11(2):18-121, 2010.

[21] Efe, S.I. and Ojoh, C.O. "Climate Variability and Commercial Activities in Warri Metropolis, Nigeria" Journal of Social and Management Sciences, 6(3):61 - 68, 2011.

[22] Craft, W.A., Janvia, B.B. \& Yatawara, C.S. “Airborne outbreak of Ireitcothein toxicosis". Atmospheric Environment, 20:516-522, 1986.

[23] Benka-Coker,M.O. \& Ekundayo,J.A “Applicability of Evaluating the ability of microbes isolated from an oil spill site to degrade oil". Environmental Monitoring and Assessment 45:259-272, 1997. 